\title{
Interaction of interferon alpha therapy with thyroid function tests in the management of hepatitis C: a case report
}

\author{
Gurmit Gill ${ }^{1 *}$, Hammad Bajwa' ${ }^{1}$ Peter Strouhal ${ }^{2}$ and Harit N. Buch ${ }^{1}$
}

\begin{abstract}
Background: Interferon alpha is a widely used therapeutic agent in the treatment of hepatitis $C$ virus infection. Clinical thyroid disease is seen in nearly $15 \%$ of patients receiving interferon alpha for hepatitis C virus infection. The mechanism of thyroid dysfunction with interferon alpha is either autoimmune or inflammatory. We report a case of young woman who developed biphasic thyroid dysfunction posing a diagnostic challenge, while receiving interferon alpha treatment for hepatitis $C$ virus infection.
\end{abstract}

Case presentation: A 29-year-old, Caucasian woman with type 1 diabetes and hepatitis $C$ virus infection was referred with hyperthyroidism, while she was at 17 weeks of a planned 24-week course of interferon alpha therapy. A laboratory investigation revealed a thyroid stimulation hormone level of $0.005 \mathrm{mU} / \mathrm{L}(0.350-4.94)$, free thyroxine of $45.6 \mathrm{pmol} / \mathrm{L}$ (9.0-19.0) and free tri-iodothyronine of $12.6 \mathrm{pmol} / \mathrm{L}(2.6-5.7)$. She had a mild neutropenia and alanine aminotransferase at double the reference value. Her thyroid peroxidase antibody level was $497 \mathrm{ku} / \mathrm{L}(<5.6)$ and thyroid inhibitory factor 7 IU/L (>1.8 iu/l is positive). Thyroid scintigraphy with technetium99 scan confirmed a normal-sized thyroid gland with diffuse but normal overall uptake. A diagnosis of interferon alpha-triggered autoimmune hyperthyroidism as opposed to an inflammatory thyroiditis was made. She was offered radioactive iodine therapy, as thionamides were considered inappropriate in view of her liver disease and mild neutropenia. Due to our patient's personal circumstances, radioactive iodine therapy was delayed by 8 weeks and her thyrotoxic symptoms were controlled with betablockers alone. A repeat thyroid function test, 4 weeks post treatment with interferon alpha, indicated spontaneous conversion to hypothyroidism with a thyroid stimulation hormone level of $100 \mathrm{mU} / \mathrm{L}$, free thyroxine of $5.2 \mathrm{pmol} / \mathrm{L}$ and free tri-iodothyronine of $1.7 \mathrm{pmol} / \mathrm{L}$. She subsequently received levothyroxine for 4 months only and had remained euthyroid for the last 3 months without any treatment.

Conclusions: Initial investigations favored the autoimmune nature of hyperthyroidism but follow-up of the case, interestingly, was more consistent with inflammatory thyroiditis. We propose that this can be explained either on the basis of autoimmune subacute thyroiditis or a change in the nature of thyroid stimulation hormone receptor antibody production from stimulating-type to blocking-type antibodies, with disappearance of the latter on discontinuation of interferon alpha.

Keywords: Hepatitis C virus, Interferon alpha, Hyperthyroidism, Hypothyroidism, Autoimmune

\footnotetext{
* Correspondence: gkggill@doctors.org.uk

${ }^{1}$ Department of Endocrinology and Diabetes, New Cross Hospital,

Wolverhampton WV10 0QP, UK

Full list of author information is available at the end of the article
} 


\section{Background}

Interferon alpha is a widely used therapeutic agent and is employed in the treatment of hepatitis $C$ virus infection $(\mathrm{HCV})[1]$. However, up to $15 \%$ of patients receiving interferon alpha for $\mathrm{HCV}$ infection can develop clinical thyroid disease [2]. The precise relationship between interferon alpha therapy and the development of thyroid pathology can be complex and the mechanism of thyroid dysfunction should be assessed in each patient prior to initiation of treatment. We present a case where therapeutic decisions were difficult to make in view of the unusual course of thyroid dysfunction.

\section{Case presentation}

A 29-year-old, Caucasian woman with HCV (genotype 3) was referred from a gastroenterology clinic with hyperthyroidism, diagnosed on routine thyroid function testing. She had a 23-year history of type 1 diabetes, which was complicated by nephropathy and proliferative retinopathy and for which she was on a multiple-dose insulin regime. She reported a 6-kg weight loss, heat intolerance, and amenorrhoea in the preceding 3 months. On examination, she had mild positional tremor but no other clinical features of hyperthyroidism. She did not have a palpable goiter or thyroid eye disease. At the time of referral she had been receiving interferon alpha therapy $\left(180\right.$ mcg Pegasys ${ }^{\oplus}$ once weekly by subcutaneous administration) for 17 weeks of a planned 24-week course of treatment, in addition to $800 \mathrm{mg}$ Copegus daily by oral administration.

A laboratory investigation revealed a thyroid stimulation hormone (TSH) level of $0.005 \mathrm{mU} / \mathrm{L}$ (reference range $0.350-4.94)$, free thyroxine $\left(\mathrm{FT}_{4}\right)$ of $45.6 \mathrm{pmol} / \mathrm{L}(9.0-$ 19.0) and free tri-iodothyronine $\left(\mathrm{FT}_{3}\right)$ of $12.6 \mathrm{pmol} / \mathrm{L}$ (2.6-5.7). Her hemoglobin was $127 \mathrm{~g} / \mathrm{L}$ (115-165), white cell count $1.8 \times 10 \mathrm{E} 9 / \mathrm{L}(4.0-11.0)$, platelets $118 \times 10 \mathrm{E} 9 / \mathrm{L}$ (150-450) neutrophils $1.0 \times 10 \mathrm{E} 9 / \mathrm{L}(2.0-7.5)$, bilirubin 7 umol/L (0-20), alkaline phosphatase $63 \mathrm{iu} / \mathrm{L}$ (30-130), alanine transaminase $120 \mathrm{iu} / \mathrm{L}(<55)$, albumin $32 \mathrm{~g} / \mathrm{L}$ (35-50) and she had normal renal function. Her thyroid peroxidase (TPO) antibody level was $497 \mathrm{ku} / \mathrm{L}(<5.6)$ and thyroid inhibitory factor was $7 \mathrm{IU} / \mathrm{L}(<1.0 \mathrm{iu} / \mathrm{L}$ is negative, $1.0-1.8 \mathrm{iu} / \mathrm{L}$ is borderline, $>1.8 \mathrm{iu} / \mathrm{L}$ is positive). A thyroid scintigraphy with technetium99 scan (Radionucleotide (RN) scan) revealed a normal-sized thyroid gland with diffuse but normal overall uptake but not suppressed (Figs. 1 and 2).

On the basis of the above investigations she was suspected to have interferon alpha-triggered hyperthyroidism related to a diffuse autoimmune process as opposed to an inflammatory thyroiditis. In view of persistent hyperthyroidism over subsequent weeks and the likelihood of the autoimmune process to continue after withdrawal of interferon alpha, it was decided to initiate specific therapy to control hyperthyroidism. Thionamides were

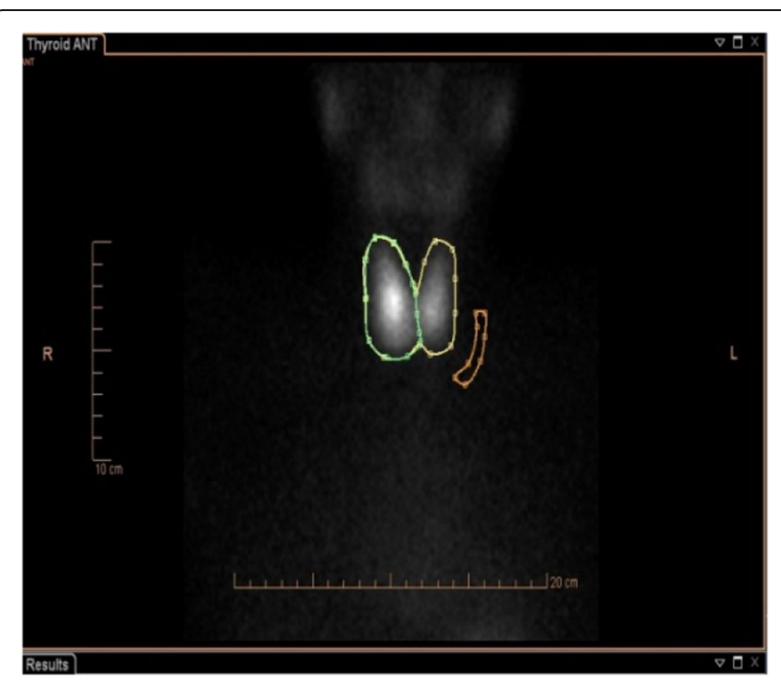

Fig. 1 Radionuclide images

not considered appropriate in view of her history of liver disease and suppressed neutrophil count and a decision was made to administer radioiodine (RAI) therapy for which she was appropriately counselled. However, due to our patient's personal circumstances, RAI therapy was delayed by 8 weeks and her hyperthyroid symptoms were controlled with beta-blockers. During this period she completed her 24-week interferon alpha therapy and when she presented for her pre-RAI assessment she had been off interferon for 4 weeks. A repeat thyroid function test indicated spontaneous conversion to hypothyroidism with a TSH level of $100 \mathrm{mU} / \mathrm{L}, \mathrm{FT}_{4}$ of $5.2 \mathrm{pmol} / \mathrm{L}$, and $\mathrm{FT}_{3}$ of $1.7 \mathrm{pmol} / \mathrm{L}$. Repeat biochemical testing 3 weeks later confirmed persistent hypothyroidism and, in view of her significant symptoms, she was commenced on thyroxine replacement. She remained euthyroid on $100 \mathrm{mcg}$ thyroxine over the next 4 months. At the end of this period thyroxine was withdrawn, and when last seen 3 months later she had remained euthyroid off thyroxine and was hepatitis $\mathrm{C}$ virus free.

\section{Discussion}

Interferon alpha is the cornerstone of therapy for hepatitis $\mathrm{C}$ infection (HCV) [1, 3, 4]. It can achieve a sustained virological response in up to $50 \%$ of patients and hence has been widely used as therapeutic agent in patients with $\mathrm{HCV}$ infection. However, new-onset thyroid dysfunction is a major side effect and prevalence rates of up to $15 \%$ have been reported [2].

The mechanism of thyroid dysfunction with interferon alpha is either autoimmune or inflammatory [5]. In one series of 321 patients, of the 10 patients who developed hyperthyroidism, 6 had an autoimmune presentation while the other 4 patients had destructive thyroiditis [6]. Most other series report a fairly even distribution 


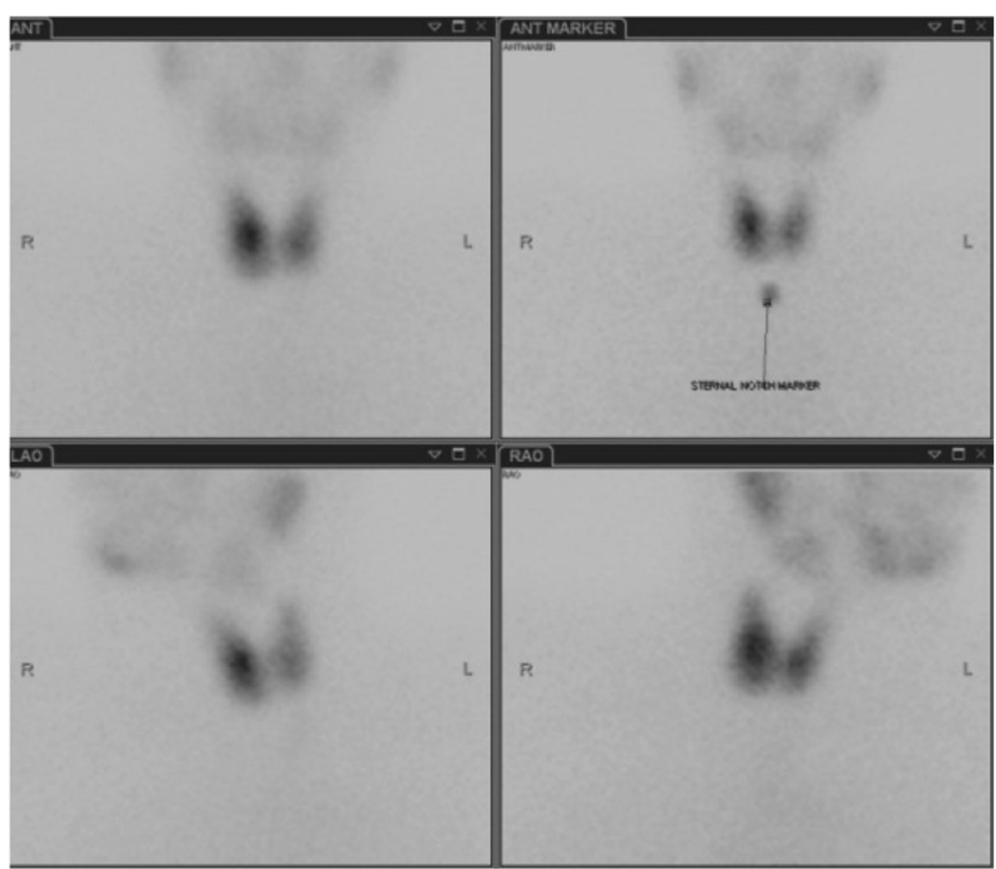

Fig. 2 Radionuclide images

between the prevalence of the two types of thyroid dysfunction [7].

The diverse effects of interferon alpha on the immune system that leads to its therapeutic actions are also responsible for the development of autoimmunity. It binds to interferon alpha receptors, which are transmembrane glycoproteins-containing cytoplasmic domains. As a result it activates various signaling pathways, including the Janus kinase/signal transducer and activator of transcription (JAK-STAT) pathway, the proto-oncogene Crk (Crk) pathway, the insulin receptor signaling (IRS) signaling pathway and the mitogen-activated protein (MAP) kinase pathway, which in turn leads to activation of a large number of interferon-stimulated genes (ISGs) including cytokine and adhesion molecule genes [8-10]. Interferon alpha induced increased expression of MHC class 1 antigens on the thyroid cells is another possible mechanism of stimulating autoimmunity. Interferon alpha also shifts the immune response to a type 1 helper (Th1)-mediated pattern $[11,12]$, resulting in the production of potent pro-inflammatory cytokines including interferon gamma (IFN- $\gamma$ ) and interleukin-2 (IL-2), thereby stimulating autoimmunity [13, 14]. Other possible mechanisms include stimulation of interleukin-6 (IL-6) release, enhancement of the activity of neutrophils, lymphocytes, macrophages and natural killer (NK) cells, all of which can potentially contribute to development of autoimmunity-mediated inflammatory response $[15,16]$. It has also been demonstrated from molecular studies that $\mathrm{HCV}$ proteins could independently impact and contribute to autoimmune thyroid dysfunction [17] through the binding of HCV glycoproteins to CD8 receptors expressed on thyroid cells and inducing a cascade of signaling pathways leading to interleukin-8 (IL-8) release.

Forty percent of patients who develop thyroid dysfunction while on interferon alpha therapy become thyroid antibody positive, and antibodies prior to initiation of interferon alpha therapy have a positive predictive value of $67 \%$ for the development of thyroid dysfunction [7]. Patients who progress to hyperthyroidism demonstrate a significant rise in thyroid antibody levels [18]. This has led to the recommendation that thyroid antibody testing should be undertaken prior to initiation of interferon alpha therapy. Other predictors include female gender and lower $\mathrm{FT}_{3}$ levels $[7,19]$.

Inflammatory non-autoimmune thyroiditis is usually a destructive process occurring within the gland. It results from the direct effect of interferon alpha on thyroid cells with inhibition of TSH-induced gene expression of thyroglobulin, TPO, and sodium iodide symporter as shown in various laboratory studies [20].

The clinical course of autoimmune thyroid dysfunction is similar to that of Graves' disease and patients require standard anti-thyroid management especially as, in most cases, withdrawal of interferon alpha does not lead to resolution of hyperthyroidism $[6,13,21]$ and patients remain thyroid antibody-positive $[6,13,21]$. Use of antithyroid drugs has to be carefully considered in view of the hepatic dysfunction and neutropenia that accompanies the use of interferon alpha. On the other hand, 
inflammatory non-autoimmune thyroid dysfunction is clinically characterized by three phases, that is sudden onset of hyperthyroidism, followed by a hypothyroid state and eventually resolution and normalization of thyroid function, which can take several weeks to months [22]. As spontaneous resolution is expected, anti-thyroid therapy is not required for management of hyperthyroidism. Beta-blockers are used for symptomatic benefit and, during the hypothyroid phase, patients may require thyroxine with planned withdrawal after 3-6 months. Five percent of patients have permanent hypothyroidism and patients who have complete recovery remain susceptible to recurrence on being re-exposed to interferon alpha.

In view of its impact on the management strategy, it is important to identify the mechanism of interferon alpha-induced thyroid dysfunction with appropriate investigations. Thyroid antibodies, more specifically TSH receptor antibodies and radionuclide uptake scans are helpful in making this distinction. Positive antibodies with non-suppressed radionuclide uptake suggest an autoimmune process while negative antibodies with suppressed radionuclide uptake would support inflammatory thyroiditis.

In summary, the case emphasizes the need to assess the risk of development of thyroid dysfunction prior to commencement of interferon alpha in patients with HCV infection and to monitor such patients closely clinically and biochemically. It also highlights the importance of appropriate investigations to elucidate the possible mechanism of thyroid dysfunction prior to formulating management plans, although an unexpected pattern of thyroid dysfunction is occasionally encountered, as in our patient.

\section{Conclusions}

Our patient had an unexpected course of hyperthyroidism. She had several features to suggest an autoimmune process with her background of autoimmune type 1 diabetes; positive TSH receptor antibodies and a nonsuppressed radionuclide uptake scan, undertaken during significant hyperthyroidism. While waiting for definitive management in the form of RAI therapy, she spontaneously reverted to hypothyroidism, which was transient, and our patient eventually staged a full recovery of thyroid function. This sequence of thyroid dysfunction was suggestive of destructive thyroiditis rather than diffuse autoimmune hyperthyroidism. The explanation for the discrepancy between investigation results and the clinical course was unclear. Positive antibodies and biphasic thyroid dysfunction can be explained on the basis of autoimmune subacute thyroiditis. However this is not supported by radionuclide scan, which would be expected to show suppressed uptake in inflammatory thyroiditis of any etiology. A change in iodine status has been linked to fluctuating and varying thyroid status in patients on interferon alpha [23]. However our patient had been residing in the UK for a number of years and there were no other factors to suspect this possibility. A more likely explanation is a change in the nature of antibody production from stimulating-type to blocking-type antibodies, with disappearance of the latter on discontinuation of interferon alpha. This was difficult to confirm, as assays for identifying subtypes of TSH receptor antibodies are not readily available. The changing nature of antibodies has been observed anecdotally in other situations of induced autoimmune process. A similar course was also reported in a series of four patients following the use of alemtuzumab for multiple sclerosis, with one of the patients developing hypothyroidism soon after the initial presentation with hyperthyroidism [24].

\section{Abbreviations}

Crk: Proto-oncogene $\mathrm{Crk}_{3} \mathrm{FT}_{3}$ : Tri-iodothyronine; $\mathrm{FT}_{4}$ : Free thyroxine; HCV: Hepatitis C virus; IFN-y: Interferon gamma; IL-2: Interleukin-2; IL-6: Interleukin-6; IL-8: Interleukin-8; IRS: Insulin receptor signaling; ISGs: Interferon-stimulating genes; JAK-STAT: Janus kinase/signal transducer and activator of transcription; MAP: Mitogen-activated protein; NK: Natural killer; RAl: Radioiodine; Th1: Type 1 helper cells; TPO: Thyroid peroxidase; TSH: Thyroid-stimulating hormone

\section{Acknowledgements}

None.

Funding

There has been no source of funding for the preparation of this manuscript.

Availability of data and materials

No other patient data has been used in the preparation of this manuscript.

\section{Authors' contributions}

GG and HB analyzed and interpreted the patient data and wrote up the original draft. PS performed the thyroid scintigraphy and provided the report. HNB supervised and reviewed the writing of manuscript. All authors read and approved the final manuscript.

\section{Authors' information}

GG is a specialist registrar in endocrinology and diabetes. $\mathrm{HB}$ is a specialist registrar in endocrinology and diabetes.

PS is a consultant radiologist.

$\mathrm{HNB}$ is a consultant endocrinologist.

\section{Competing interests}

The authors declare that they have no competing interests.

\section{Consent for publication}

Written informed consent was obtained from the patient for publication of this case report and any accompanying images. A copy of the written consent is available for review by the Editor-in-Chief of this journal.

\section{Author details}

'Department of Endocrinology and Diabetes, New Cross Hospital, Wolverhampton WV10 0QP, UK. ²Department of Radiology, New Cross Hospital, Wolverhampton WV10 0QP, UK.

Received: 12 February 2016 Accepted: 9 August 2016

Published online: 15 September 2016

References

1. Walter MR, Bordens R, Nagabhushan TL, Williams BRG, Herberman RB, Dinarello CA, et al. Review of recent developments in the molecular characterization of recombinant alfa interferons on the 40th anniversary of the discovery of interferon. Cancer Biother Radiopharm. 1998b;13(3):143-54. 
2. Tomer Y, Blackard JT, Akeno N. Interferon alpha treatment and thyroid dysfunction. Endocrinol Metab Clin N Am. 2007;36(4):1051-66.

3. Burman $P$, Totterman $T H$, Öberg K, Karlsson FA. Thyroid autoimmunity in patients on long-term therapy with leukocyte-derived interferon. J Clin Endocrinol Metab. 1986;63(5):1086-90.

4. Baron S. The interferons. Mechanisms of action and clinical applications. JAMA. 1991;266(10):1375-83.

5. Fentiman I, Thomas B, Balkwill F, Rubens R, Hayward J. Primary hypothyroidism associated with interferon therapy of breast cancer. Lancet. 1985;325(8438):1166.

6. Wong V, Fu AX-L, George J, Cheung NW. Thyrotoxicosis induced by alphainterferon therapy in chronic viral hepatitis. Clin Endocrinol. 2002;56(6):793-8.

7. Roti E, Minelli R, Giuberti T, Marchelli S, Schianchi C, Gardini E, et al. Multiple changes in thyroid function in patients with chronic active HCV hepatitis treated with recombinant interferon-alpha. Am J Med. 1996;101(5):482-7.

8. Manns MP, McHutchison JG, Gordon SC, Rustgi VK, Shiffman M, Reindollar R, et al. Peginterferon alfa-2b plus ribavirin compared with interferon alfa- $2 b$ plus ribavirin for initial treatment of chronic hepatitis $\mathrm{C}$ : a randomised trial. Lancet. 2001;358(9286):958-65.

9. Parmar S, Platanias LC. Interferons: mechanisms of action and clinical applications. Curr Opin Oncol. 2003;15(6):431-9.

10. Jonasch E. Interferon in oncological practice: review of interferon biology, clinical applications, and toxicities. Oncologist. 2001;6(1):34-55.

11. Farrar JD, Murphy KM. Type I interferons and T helper development. Immunol Today. 2000;21(10):484-9

12. Tilg H. New insights into the mechanisms of interferon alfa: an immunoregulatory and anti-inflammatory cytokine. Gastroenterology. 1997;112(3):1017-21.

13. Kodama T, Katabami S, Kamijo K, Katanuma A, Yamashita K, Azuma N, et al. Development of transient thyroid disease and reaction during treatment of chronic hepatitis C with interferon. J Gastroenterol. 1994;29(3):289-92.

14. Marazuela M, Garcia-Buey L, Gonzalez-Fernandez B, Garcia-Monzon C, Arranz A, Borque MJ, et al. Thyroid autoimmune disorders in patients with chronic hepatitis $C$ before and during interferon-alpha therapy. Clin Endocrinol. 1996;44(6):635-42

15. Crotta S, Stilla A, Wack A, D'Andrea A, Nuti S, D'Oro U, et al. Inhibition of natural killer cells through engagement of $C D 81$ by the major hepatitis $C$ virus envelope protein. J Exp Med. 2001;195(1):35-41.

16. Wack A, Soldaini E, Tseng C-TK, Nuti S, Klimpel GR, Abrignani S. Binding of the hepatitis $C$ virus envelope protein $\mathrm{E} 2$ to $\mathrm{CD} 81$ provides a co-stimulatory signal for human T cells. Eur J Immunol. 2001;31(1):166-75.

17. Balasubramanian A. Hepatitis C, virus and HIV envelope proteins collaboratively mediate interleukin-8 secretion through activation of p38 MAP kinase and SHP2 in hepatocytes. J Biol Chem. 2003;278(37):35755-66.

18. Preziati D, La Rosa L, Covini G, Marcelli R, Rescalli S, Persani L, et al. Autoimmunity and thyroid function in patients with chronic active hepatitis treated with recombinant interferon alpha-2a. Eur J Endocrinol. 1995b; 132(5): 587-93.

19. Monzani F, Caraccio N, Dardano A, Ferrannini E. Thyroid autoimmunity and dysfunction associated with type I interferon therapy. Clin Exp Med. 2004;3(4):199-210.

20. Caraccio N, Giannini R, Cuccato S, Faviana P, Berti P, Galleri D, et al. Type I interferons modulate the expression of thyroid peroxidase, sodium/iodide symporter, and thyroglobulin genes in primary human thyrocyte cultures. J Clin Endocrinol Metab. 2005;90(2):1156-62.

21. Lisker-Melman M, Di Bisceglie AM, Usala SJ, Weintraub B, Murray LM, Hoofnagle $\mathrm{JH}$. Development of thyroid disease during therapy of chronic viral hepatitis with interferon alpha. Gastroenterology. 1992;102(6):2155-60.

22. Fried MW, Shiffman ML, Reddy KR, Smith C, Marinos G, Gonçales FL, et al. Peginterferon alfa-2a plus ribavirin for chronic hepatitis $C$ virus infection. N Engl J Med. 2002;347(13):975-82.

23. Antonelli A, Ferri C, Pampana A, Fallahi P, Nesti C, Pasquini M, et al. Thyroid disorders in chronic hepatitis C. Am J Med. 2004:117(1):10-3.

24. Aranha A, Amer S, Reda E, Broadley S, Davoren P. Autoimmune thyroid disease in the use of alemtuzumab for multiple sclerosis: a review. Endocr Pract. 2013;19(5):821-8.

\section{Submit your next manuscript to BioMed Central and we will help you at every step:}

- We accept pre-submission inquiries

- Our selector tool helps you to find the most relevant journal

- We provide round the clock customer support

- Convenient online submission

- Thorough peer review

- Inclusion in PubMed and all major indexing services

- Maximum visibility for your research

Submit your manuscript at www.biomedcentral.com/submit

) Biomed Central 